\title{
Settlement strategy in Symplectophyllum (Cnidaria, Rugosa)
}

\author{
JOHN W. PICKETT
}

Honorary Research Associate, Geological Survey of New South Wales, W.B. Clarke Geoscience Centre, 947-953 Londonderry Road, Londonderry NSW 2573, Australia; picketj@bigpond.net.au.

\begin{abstract}
The early ontogeny of the solitary rugose coral Symplectophyllum from the late Tournaisian - early Viséan of New South Wales is described. The genus is frequently associated with the phaceloid tabulate coral Syringopora, individuals of the former genus occurring within the coralla of the latter, and growing in tandem. A similar association also occurs between Symplectophyllum and the rugosan genera Cionodendron and Pickettodendron, though less commonly. The phaceloid genera suffer periodic mortality events, causing breaks in vertical growth; the settlement of Symplectophyllum larvae appears to be associated with these events. Larvae settle on algal incrustations of the epitheca of the phaceloid corals, not on the epitheca itself. The manner in which Symplectophyllum corallites acquired space for growth suggests the presence of sweeper tentacles in Rugosa.
\end{abstract}

KEYWORDS: Ontogeny, settlement strategy, Carboniferous, Syringopora, Symplectophyllum, mortality crisis, ecology, sweeper tentacles

\section{Introduction}

The larger solitary corals of the Early Carboniferous in eastern Australia - Amygdalophyllum Dun \& Benson, 1920, Merlewoodia Pickett, 1967 and Symplectophyllum Hill, 1934 - have broad dissepimentaria characterised by an outer zone of large and irregular lonsdaleoid dissepiments, axial of which is a zone of naotic dissepiments, with regular dissepiments only the innermost zone. By contrast, the septa of the inner part of the corallite are thickened and braced by tabulae and regular dissepiments, and the axial structure is robust (except in Merlewoodia). Specimens of these genera are usually recovered as decorticated individuals, having undergone some penecontemporaneous erosion. Because of the zone of lonsdaleoid dissepiments, the outer part of the corallite is fragile, and little erosion is needed for decortication. Occasionally however, notably at a locality on "Pinaroo Plain" station at Caroda, near Bingara, New South Wales, specimens of Symplectophyllum are commonly found in growth position within larger colonies of the tabulate genus Syringopora, the growth direction of the two species being subparallel. More rarely they may be associated with branching lithostrotionids such as Cionodendron Benson \& Smith, 1923 or Pickettodendron Denayer \& Webb, 2015. The dynamics of this association form the subject of this article.

\section{Localities and age}

Two localities are the principal sources of the present material. The first, which has provided the largest number of specimens, is that already referred to on "Pinaroo Plain", where a small limestone knoll in the lower part of the Caroda Formation contains a coral fauna including Cionodendron "arundineum" (Etheridge), Australastraea parvicolumnaris (Pickett), Symplectophyllum mutatum Hill, Syringopora syrinx Etheridge and S. septatisiphon Pickett. The upper part of this knoll comprises a small patch reef in which many of the corals are still in growth position, and where colonies of $C$. "arundineum" may exceed one metre in maximum diameter. The horizon lies in the lower part of the Caroda Formation, $500 \mathrm{~m}$ north of "Pinaroo Plain" homestead, Caroda, NSW (Fig. 1), at $150^{\circ} 23$ '04”' E, 3001'39” S (McKelvey \& White, 1964; Chesnut et al., 1969). This locality is L316 of Pickett (1967), the property name "The Plain" having been replaced by "Pinaroo Plain".

The second locality lies $2 \mathrm{~km}$ WSW of the wall of Glenbawn

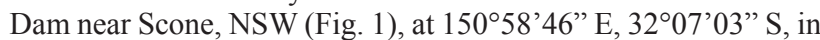
the upper part of the Dangarfield Formation (Roberts \& Oversby, 1974). Here the coral fauna includes undescribed species of Symplectophyllum, Aphrophyllum, the phaceloid lithostrotionid Pickettodendron nudum Denayer \& Webb, one, possibly two species of Syringopora, and a large massive micheliniid as well as fistuliporid and fenestellid bryozoans, de-silicified haplistiid sponges, and generally small brachiopods.

A third locality, at Bingara Falls (Fig. 1, Halls Creek, Bingara, $150^{\circ} 37^{\prime} 56^{\prime \prime}$ E, 3006'46” S; L212 of Pickett (1967)) has yielded abundant material of Symplectophyllum naoticum Pickett, which may be associated with Syringopora, also abundant at the locality, but in general the material is more fragmentary. This locality is an allochthonous, though penecontemporaneous slump in the Namoi Formation, lying probably in its upper part.

The localities are different in age, though direct control through conodont assemblages is lacking and samples to date have not produced a result. The presence of Pickettodendron and Aphrophyllum at Glenbawn implies an age older than that of the "Pinaroo Plain" locality, whose assemblage includes the subcerioid Australastraea parvicolumnare; massive lithostrotionids do not appear until the latter part of the early Viséan (Denayer \& Webb, 2015). Roberts \& Oversby (1974), on the basis of brachiopod zonation, suggest that the Dangarfield Formation spans the zones of Pustula gracilis and Schellwienella cf. burlingtonensis; the stratigraphic position of the corals near the top of the formation therefore implies a horizon high in the burlingtonensis Zone, latest Tournaisian, equivalent to the anchoralis - latus conodont zone. For the locality at "Pinaroo Plain" Denayer \& Webb (2015) suggest a level late in the conjunctus conodont Zone, late early Viséan. The material reported from "Pinaroo Plain" as Lithostrotion arundineum Etheridge by Pickett (1967), transferred to Cionodendron by Denayer \& Webb (2015) and excluded from arundineum by those authors has not been re-assigned to any other species. True arundineum is a late Viséan species, according to Denayer \& Webb (2015). Percival (2010, p. 173) summarised evidence for the age of the Caroda Formation, citing Roberts et al. (1993) and Jenkins et al. (1993), indicating a middle Viséan age for the dated horizons. The field relationships being unclear, there is no assurance that the cited horizons are identical with that of the occurrence at "Pinaroo Plain" The age of the Halls Creek occurrence may be intermediate between that of the two previous localities, as it contains Aphrophyllum hallense Smith, tying it to Glenbawn, and Cionodendron instead of Pickettodendron, implying a younger age.

The material on which this work is based forms part of the fossil collections of the Geological Survey of New South Wales (numbers prefixed MMF), held at the W.B. Clarke Geoscience Centre, except for those thin sections prefixed AM, which are held at the Australian Museum, College Street, Sydney, New South Wales.

\section{Observations}

\subsection{Growth of Syringopora}

Longitudinal sections of Syringopora colonies frequently show significant growth hiatuses. At these levels there are numerous calices, undamaged but filled with muddy detritus, indicating a mortality crisis within the colony. Some corallites survived these events, and the original surface area of the colony was rapidly re-colonised by adventitious corallites, spreading laterally and then resuming upward growth. At these levels there is a layer of fine muddy detritus, suggesting that influx of mud was the cause of mortality, burying many, though not all corallites, the polyps rapidly decaying and the empty calices filling with mud. 
Figure 1. Locality map, showing area of outcrop of Carboniferous strata in New South Wales. The three localities discussed in the text are marked by stars: $\mathrm{PP}=$ Pinaroo Plain; $\mathrm{BF}=$ Bingara Falls; GB = Glenbawn Dam.

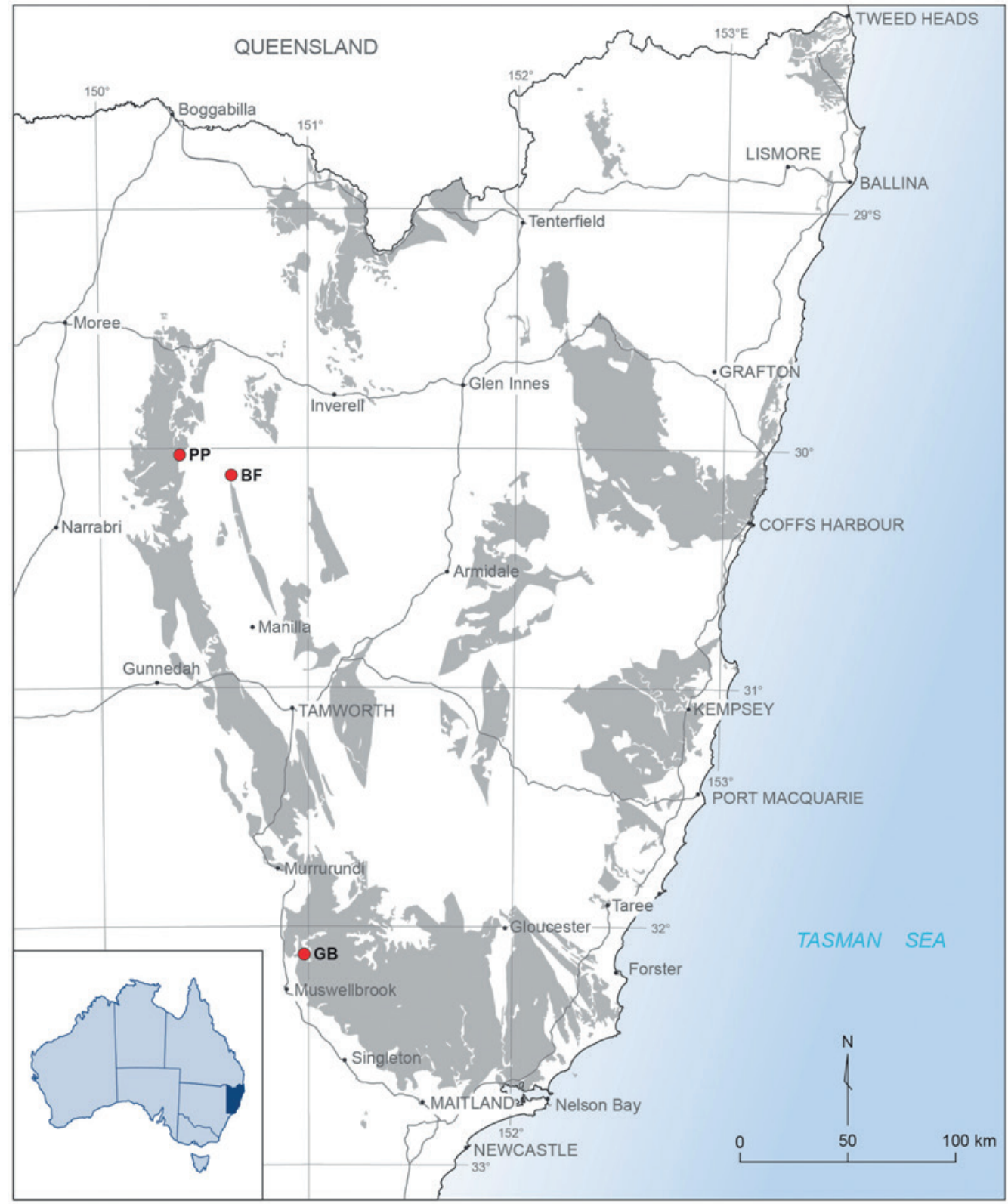

The muddy layers may laterally coalesce, when the adventitious new growth does not reach the former colony margin before the next influx. The intervals between such events in the life of the colony are irregular, as for example in specimen MMF45250 (Fig. 2) from Caroda, in which the intervals have dimensions such as $13.6 \mathrm{~mm}, 11.5 \mathrm{~mm}, 19.0 \mathrm{~mm}, 22.8 \mathrm{~mm}$ and $27.9 \mathrm{~mm}$. They are therefore more likely to be the result of some occasional phenomenon, rather than a seasonal one. Flood events, resulting in the influx of fine sediment into the ocean, seem the most likely cause of such mortality. Both the Caroda and Glenbawn localities were not far from shore, as they lie within regressive sequences, so indeed reduced salinities associated with the flooding may have been a contributing factor as well. A similar case can be observed in corals with larger corallites, as for example the Cionodendron specimen MMF45247 from Caroda (Fig. 3), which clearly shows the undamaged calices at the level of such a crisis.

Whatever the cause, the result is that the coralla form a series of superimposed layers between the mortality events, during which corallite growth is vigorous. Even the much larger corallites of Symplectophyllum may be confined to one of these layers (Fig. 4A, B), so the influx of mud regularly causes death in this coral as well, as indicated also by the common occurrence of undamaged, mud-filled calices (Fig. 4A, B). It also indicates that there is a correlation between the mortality event and the subsequent colonisation of the affected Syringopora colony by the Symplectophyllum planulae.
The phaceloid coralla of Syringopora, Cionodendron and Pickettodendron act as baffles for trapping sediment, and the relatively thin layers of mud responsible for the mortality events suggest that much of the corallum was submerged in sediment during life, with only a centimetre of so of the corallites projecting above the water-sediment interface. This is in marked contrast to the usual image of freely branching coralla growing into water. Nonetheless, there was sufficient epitheca exposed for calcareous algae to colonise it before burial, and before settlement of Symplectophyllum larvae (see below).

Corallite densities in Syringopora vary greatly, from as high as $18 / \mathrm{cm}^{2}$ in MMF45250 to only $5 / \mathrm{cm}^{2}$ in MMF44255, both from Caroda. By contrast, for Symplectophyllum this parameter runs at 0.103/ $\mathrm{cm}^{2}$ for a borrowed specimen from Caroda (Fig. 5), 0.109/ $\mathrm{cm}^{2}$ for MMF55255 (also Caroda) to $0.12 / \mathrm{cm}^{2}$ for the heavily infested MMF25300 from Glenbawn, the specimen used for serial sectioning. For much of their adult lives, the Symplectophyllum corallites remained the same size, around $10-15 \mathrm{~mm}$ (Fig. 4A, B), retaining a diameter well below that of the largest known corallites, which may exceed $40 \mathrm{~mm}$ in $S$. naoticum from Halls Creek. This phenomenon underlies the identification by Pickett (1967, p. 27) of a smaller variety of the species at Caroda.

In transverse sections of Syringopora colonies well populated with Symplectophyllum there is a zone around each solitary coral in which the Syringopora corallites are less abundant (Figs 6, 7), probably due to some interaction between the living polyps, 


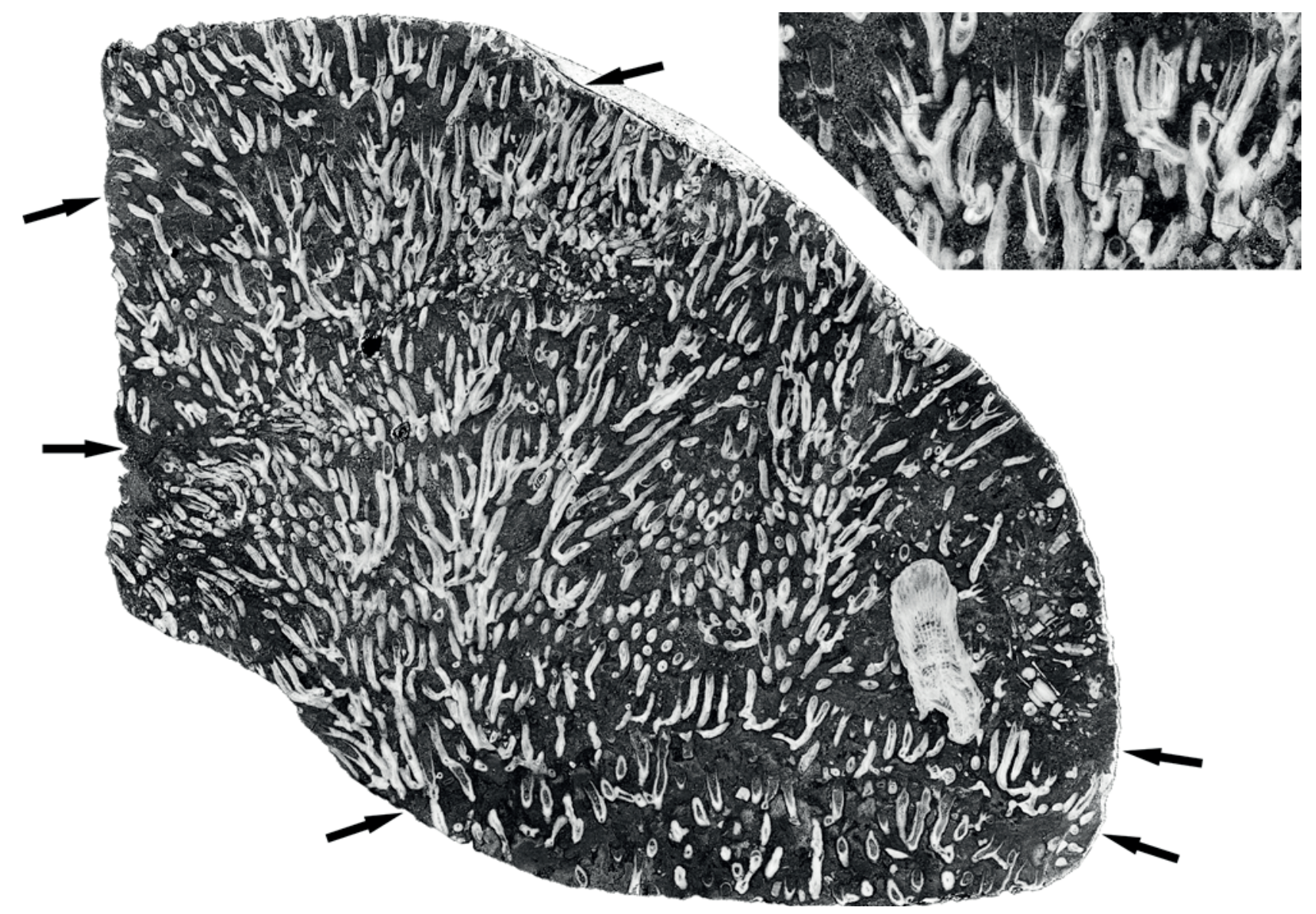

Figure 2. Vertical section of Syringopora colony, showing marked levels of mortality events (arrowed) and a single Symplectophyllum corallite. MMF45250, Caroda Formation, Pinaroo Plain, x 0.86. Inset: detail of undamaged, mud-filled calyces from below uppermost mortality event, x 1.8.

Figure 3. Cionodendron "arundineum", vertical section showing undamaged dead calyces at mortality event and a large corallite of Symplectophyllum. MMF45247, Caroda Formation, Pinaroo Plain, x 0.97 .

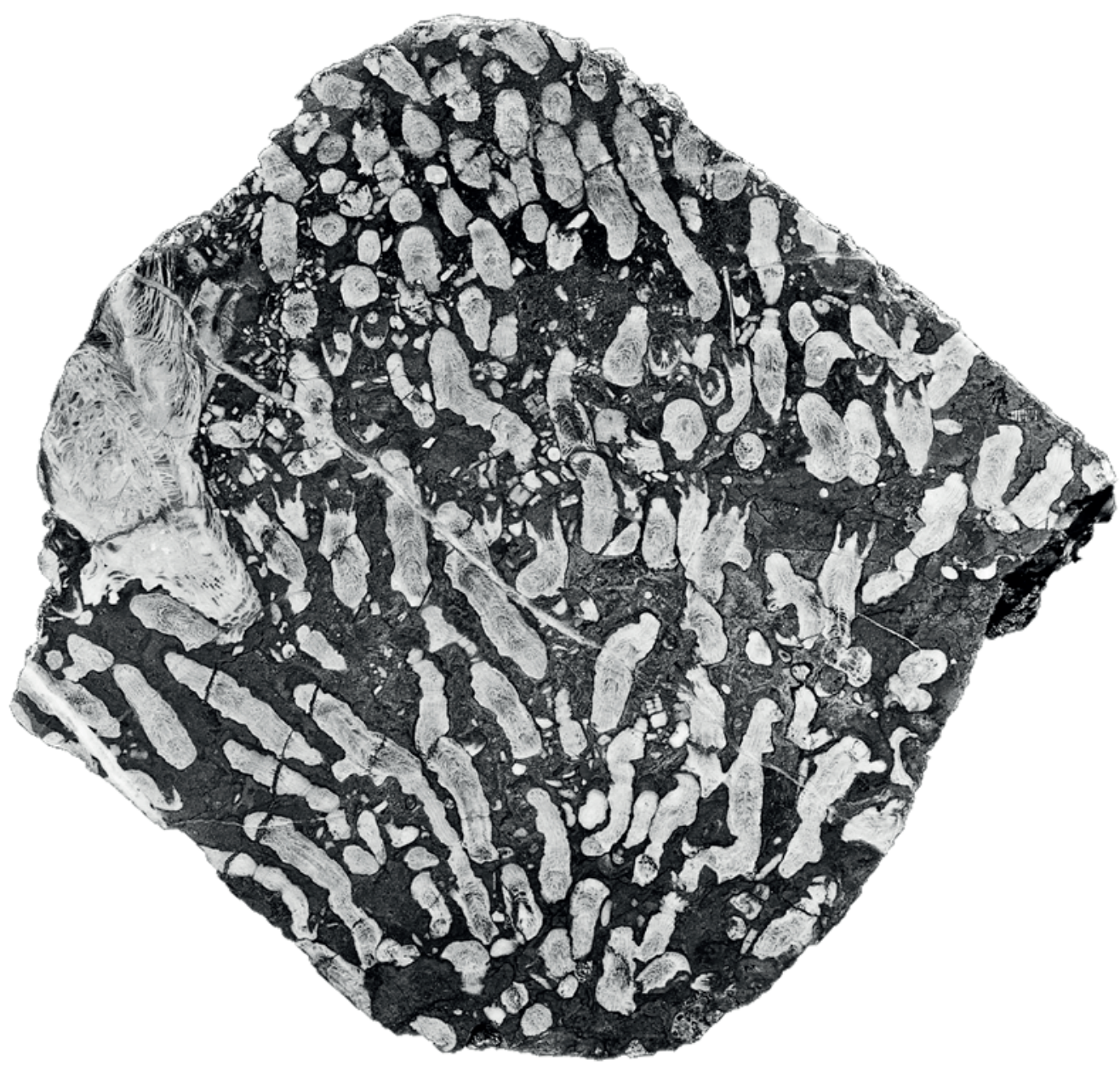


Figure 4. Symplectophyllum corallites in individual growth layers, polished surfaces of slabs. Note mudfilled, undamaged calyces. A, MMF25300, Dangarfield Formation, Glenbawn Dam, x 1.03. B, MMF45239, Caroda Formation, Pinaroo Plain, $\mathrm{x}$ 0.54 .

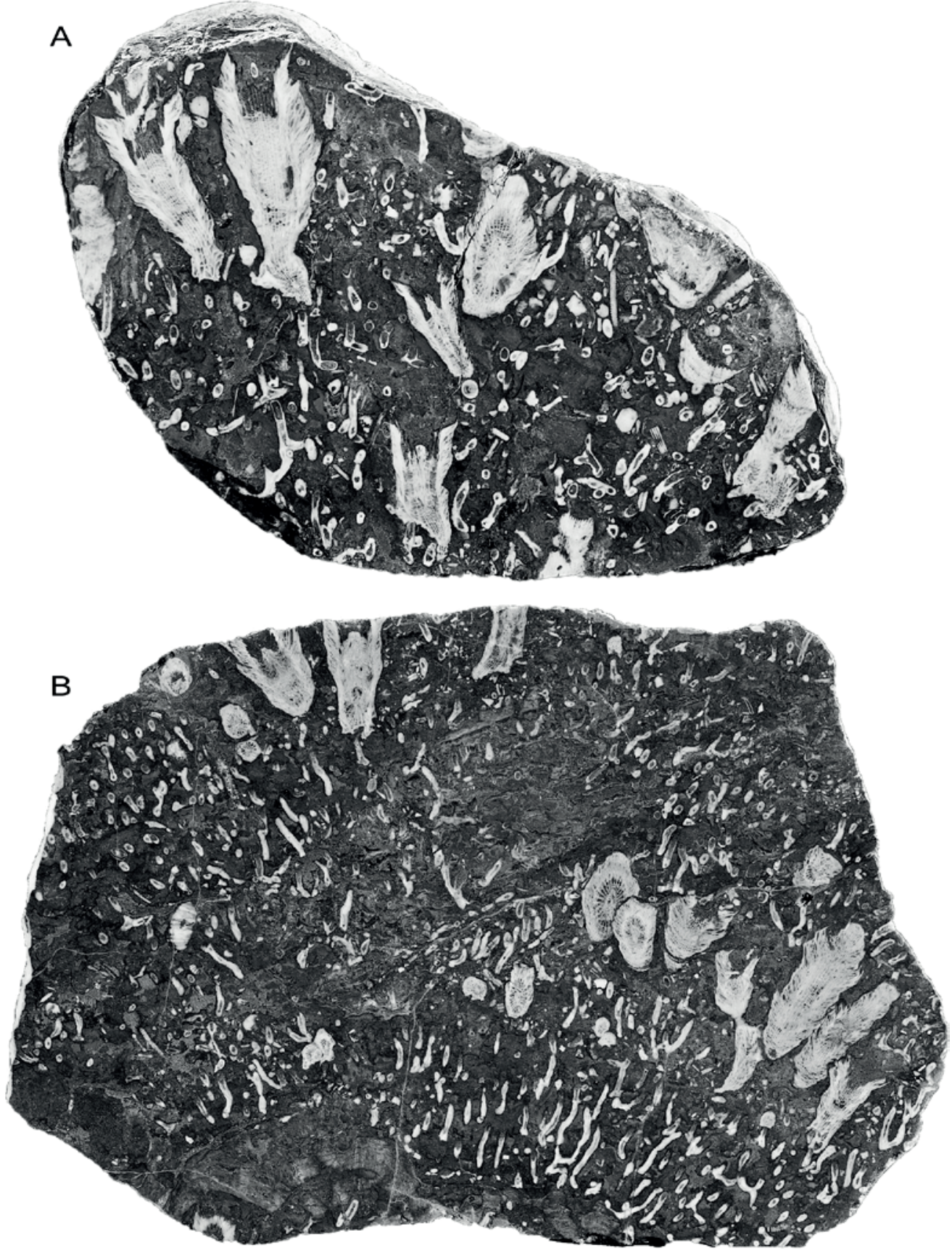

conceivably related to tentacle length, but possibly also chemical. This observation bears on the way in which the Symplectophyllum manages to increase in diameter within a host colony whose corallites are generally many times closer than the diameter of a single Symplectophyllum. For continued growth the solitary coral needs a mechanism to prevail over the nearest corallites of its host, and zone of low host-corallite density around the solitary coral provides a clue as to how this came about. The long periods of continued upward growth without much increase in diameter in Symplectophyllum suggest, on the other hand, that interaction between the two species is not one-sided. Even the largest corallites of Symplectophyllum (e.g. AM 7291, AM7292, Halls Creek; Fig. 8A, C, among the largest known) may retain the association with their host. This specimen has clearly overgrown Syringopora corallites (Fig. 8B, D), the sediment-free calices of which are sealed by the rejuvenated epitheca of Symplectophyllum, and followed immediately by renewed rejuvenation, as the space adaxial to the epitheca is colonised by Girvanella threads. Here the Symplectophyllum has overwhelmed living corallites of its host.

The achievement of such large size is possibly due, at least in some cases, to freedom from the constraints of living within a
Syringopora colony. The specimen from which the three sections AM7276, AM9147 (Fig. 9A) and AM9148 (Fig. 9B) were cut shows no associated coral. Its marginarium is undamaged, the epitheca frequently encrusted by fistuliporid bryozoans and the rejuvenation platforms occupied by threads of the alga Girvanella, indicating that at least a good proportion of the upper part of the corallite was free of surrounding sediment, and confirming that the locality lay within the photic zone (Fig. 10B). Details of the proximal part of the specimen are not available, so it may merely be a specimen which has grown ahead of its host colony.

It is probable that the presence of lonsdaleoid dissepiments in Symplectophyllum plays a significant role in its adaptation to this particular niche. Because of the lower requirement of carbonate for building the skeleton, the energetics of their formation provide a rapid means of accommodating the shape of the corallite to changes in its surroundings. Thus Berkowski (2012) was able to demonstrate that their presence in Catactotoechus enabled re-orientation of disturbed corallites on a muddy substrate by allowing rapid rejuvenescence. In the present case there is rejuvenescence as a result of mud influx, but possibly more significant is the ability provided by production of lonsdaleoid dissepiments to produce rapid growth of extensions of the 


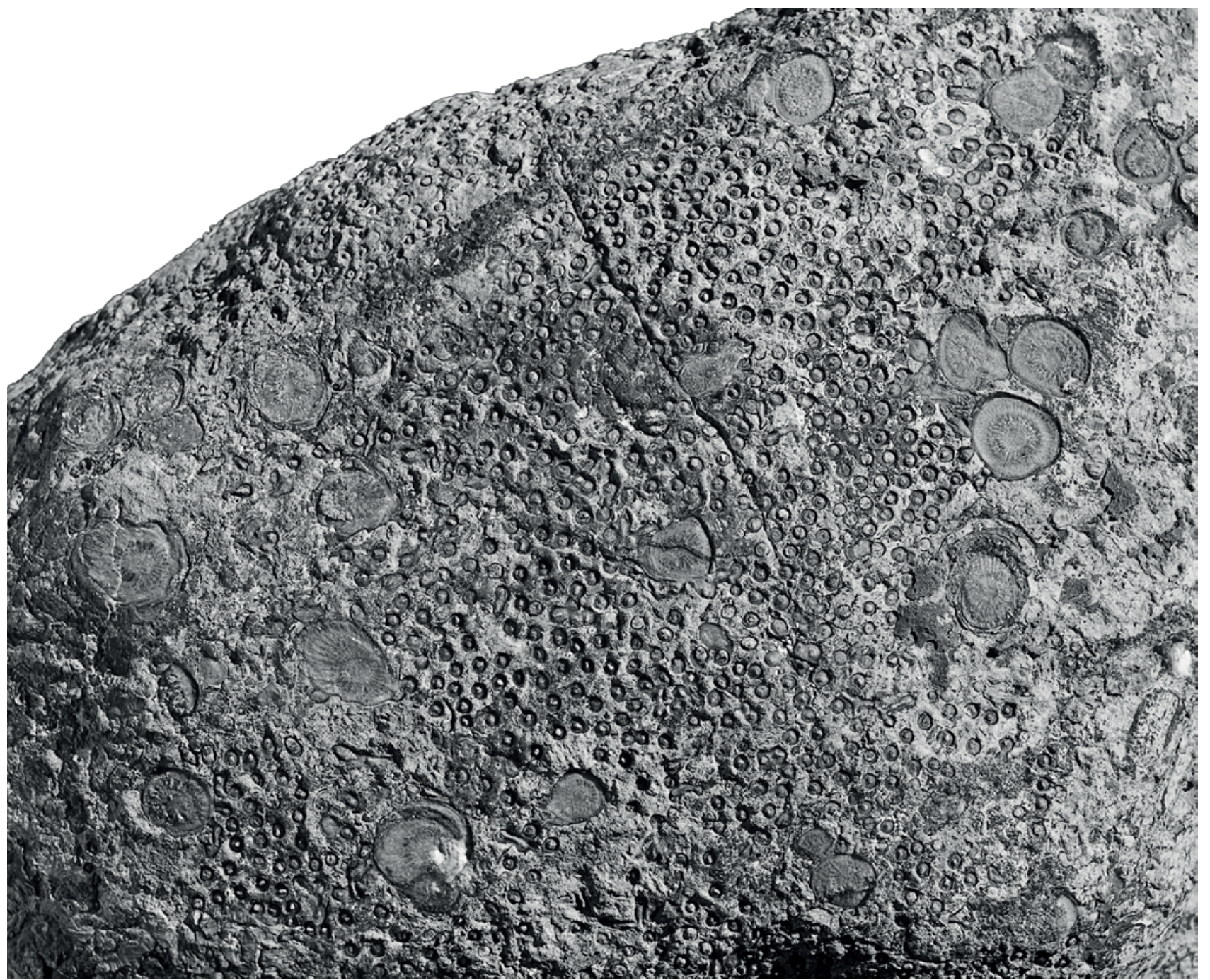

Figure 5. Symplectophyllum in Syringopora, weathered surface, Caroda Formation, Pinaroo Plain, approx..x 0.75. Specimen in private collection.

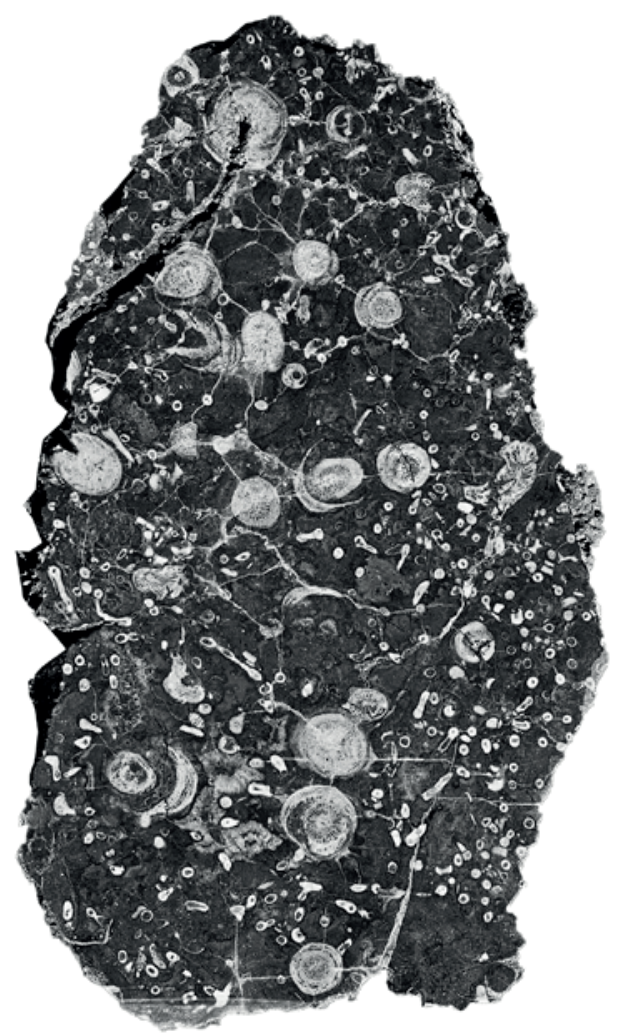

Figure 6. Symplectophyllum corallites infesting Syringopora corallum. Note generally clear areas around Symplectophyllum corallites. Transverse section, surface of slab. MMF45255, Caroda Formation, Pinaroo Plain, x 0.75.

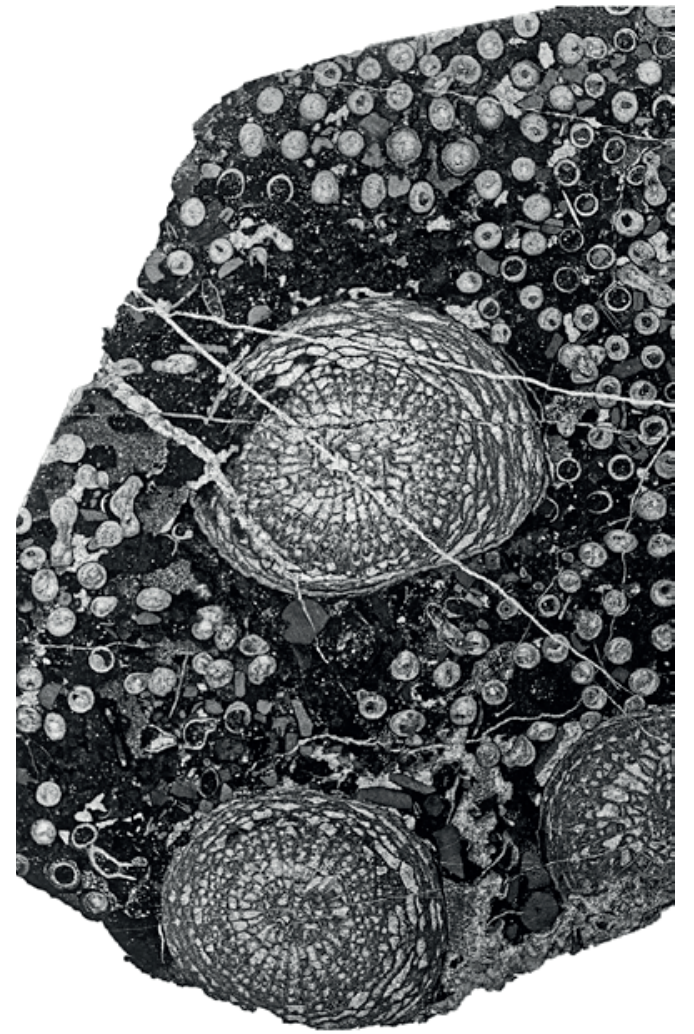

Figure 7. Corallite-poor aureolae around Symplectophyllum corallites within Syringopora colony, thin section. MMF45253, Caroda Formation, Pinaroo Plain, x 2.12. 

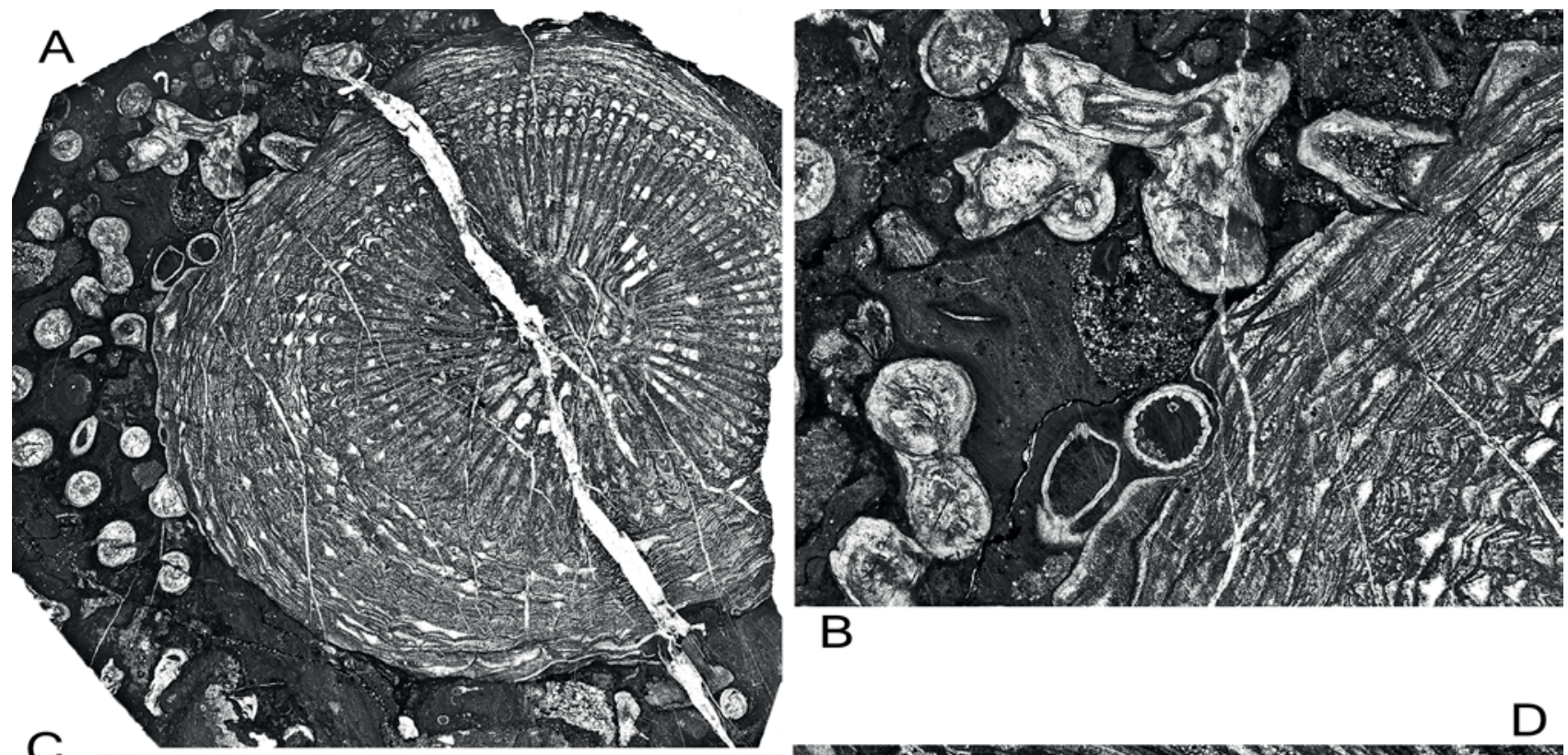

B
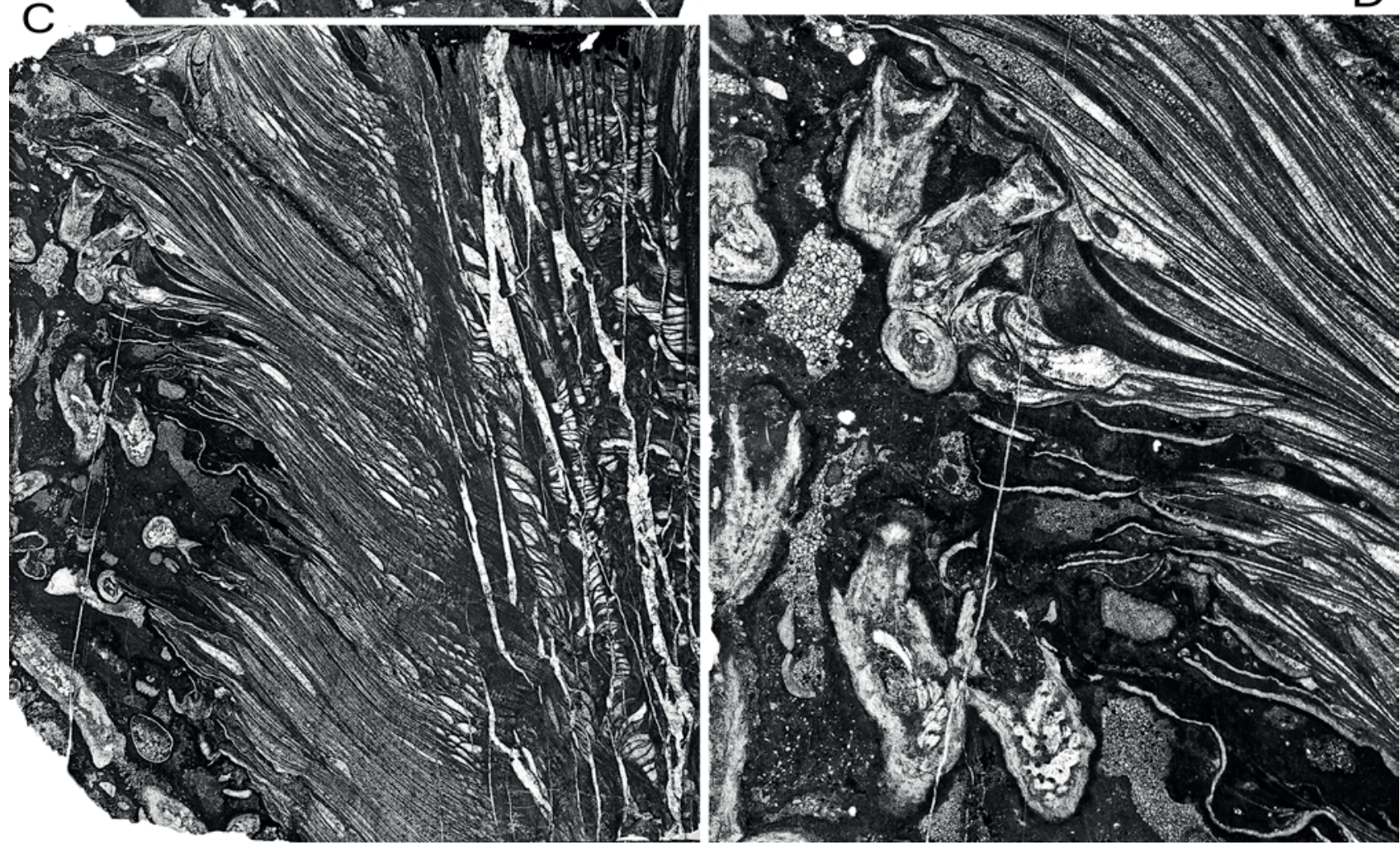

Figure 8. Symplectophyllum naoticum Pickett, holotype, showing interaction of large individual with host Syringopora. Namoi Formation, Bingara Falls. A, AM7291, transverse section of corallite, x 2.28. B, same, detail of upper left, x 5.8. C, AM7292, longitudinal section, x 2.33. D, detail of upper left, x 6.02. Note that in B and D the calyces of Syringopora are mud-filled.

corallite, which provided the means for overwhelming corallites of the host corallum. Sorauf (2007) noted the use of lonsdaleoid dissepiments by the solitary rugosan Tabulophyllum to spread rapidly over its substrate, thereby increasing its stability. Both Berkowski's and Sorauf's occurrences, however, relate to forms inhabiting a soft substrate, whereas Symplectophyllum anchors itself firmly to the hard skeleton of its host. The similarity lies in the developmental plasticity afforded by the low energy needed for rapid changes in the marginarium.

\subsection{Ontogeny of Symplectophyllum}

In the course of this study a series of sixty-four closely-spaced acetate peels was prepared from an infested Syringopora corallum from Glenbawn. From these, the early ontogeny of three Symplectophyllum individuals was examined. Detailed descriptions of these ontogenies disturb the flow of argument in this text, so are provided in a separate appendix.

In the three ontogenies described, a number of common features can be recognised: 1, the planula settled, not on the epitheca of a corallite of the host colony, but on the surface of an encrusting alga. 2, the youngest stages of skeletal development comprise the epitheca and the directional septa. Subsequent septal insertion is rather irregular. 3, the attachment side in each case was the cardinal. 4, talon-like outgrowths of the epitheca are common in very early stages. 5 , the earliest dissepiments are lonsdaleoid in form and appear well before the tabularium has reached adult diameter. Additionally, the second and third cases show that the planula could settle and survive both in areas of dead corallites and in actively growing parts of the host colony. 


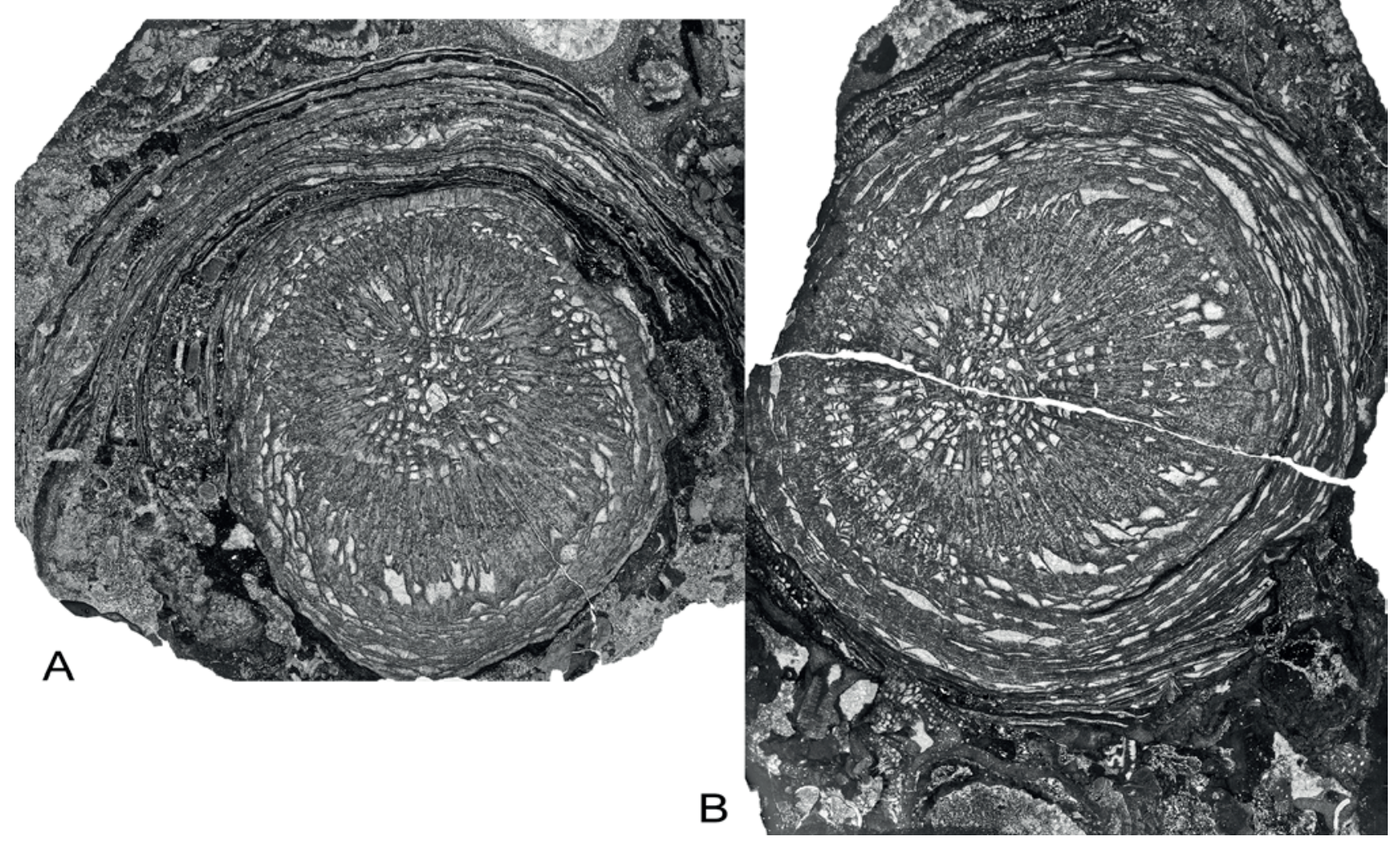

Figure 9. Symplectophyllum without Syringopora, AM9147 (left), AM9148 (right), transverse sections of same individual from Caroda Formation, Pinaroo Plain. Note extensive rejuvenation rings. Both x 2.3.

Figure 10. A, Syringopora corallite encrusting epitheca of Symplectophyllum, MMF25300, Dangarfield Formation, Glenbawn Dam, $\mathrm{x}$ 10.5. B, Threads of alga Girvanella in rejuvenation ring of Symplectophyllum, AM7276, Caroda Formation, Pinaroo Plain, $\mathrm{x}$ 34.5. C, corallites of Syringopora engulfed by Symplectophyllum, AM9144, Namoi Formation, Bingara Falls, $x$ 9.05. Note that the calyces of Syringopora are free of mud.
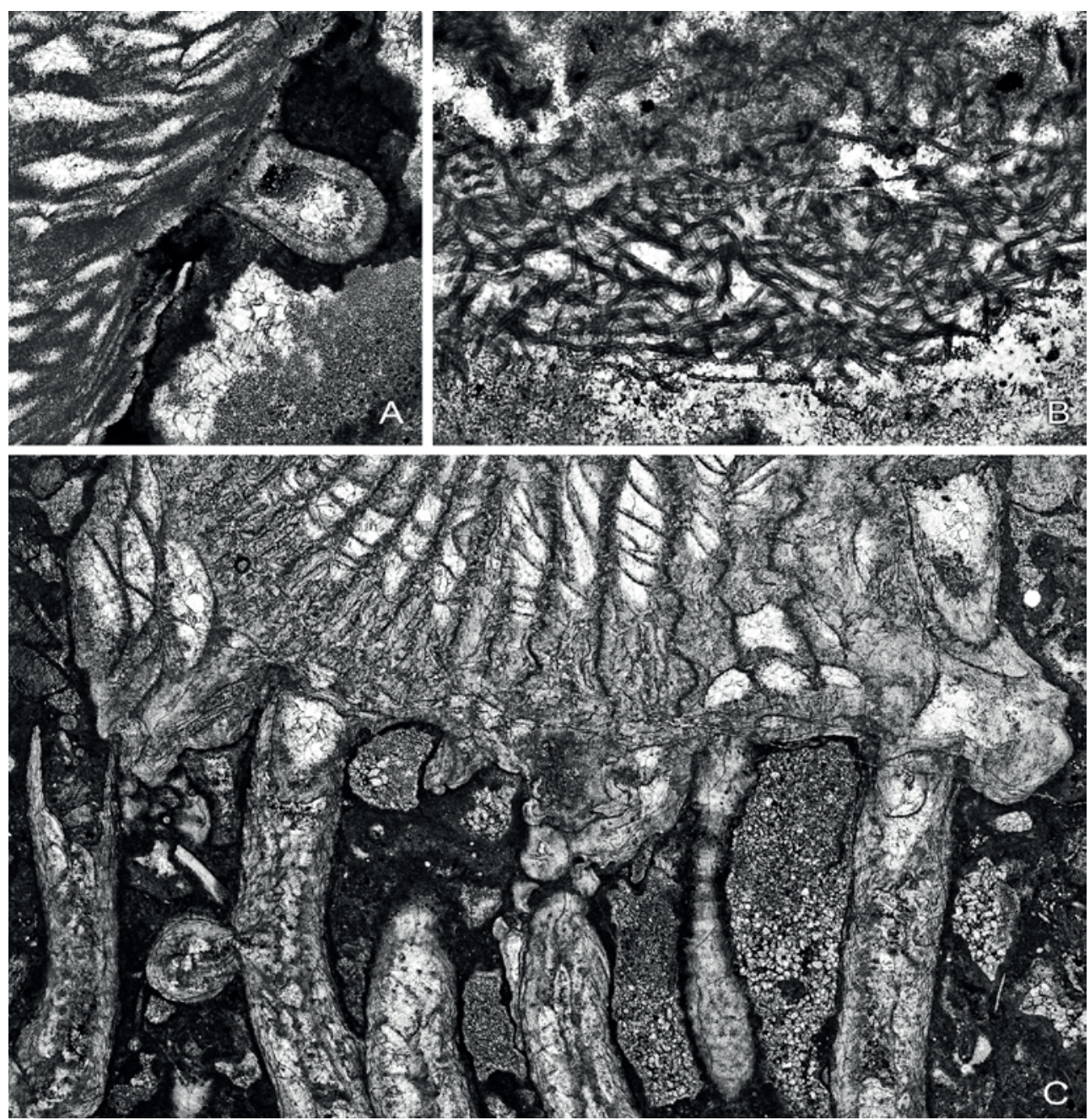


\section{Interactions}

\subsection{The space problem}

It has been shown above that corallites of Symplectophyllum may overgrow those of Syringopora which are either filled with sediment or apparently overgrown before such infilling occurred. The latter case is more significant, as it shows the probable ability of the Symplectophyllum animal to overwhelm that of Syringopora.

The relative sizes of the two species involved in this association mean that, for the Symplectophyllum to survive and continue to grow, it must create space for itself, which can only happen at the expense of the Syringopora, in which upwards of 20 corallites may occupy the same space as a single Symplectophyllum corallite. Evidence for such an antagonistic role for the solitary coral comes from the fact that the corallites of Symplectophyllum are usually surrounded by an aureola within which there are few Syringopora corallites. This is most apparent within Syringopora colonies with higher corallite densities (Fig. 7). Clearly then, the infecting species had a technique for disadvantaging its host. How this occurred is a matter of interesting speculation, but the two most obvious possibilities are either tactile, by interference involving the tentacles of the polyps, or chemical means, a more sophisticated method.

The calyces of Syringopora corallites may be free of sediment (Fig. 10C) or not (Fig. 8B, D) prior to being engulfed by the dominant Symplectophyllum. This is not of great significance. Although there is necessarily a considerable interval of time between the death of the smaller corallite and its overgrowth, simply because the Symplectophyllum needs time (days, possibly weeks) to secrete enough skeleton to close the intervening gap. If the weather is quiescent during this period, the calyces may be covered when empty of sediment; turbidity as a result of heavy weather would be sufficient to cause the alternative situation, particularly in view of the muddy environment of the whole mound.

In modern environments there is much competition for space between neighbouring coral colonies, and among scleractinians inter-specific aggression is usually achieved either by expanded mesenterial filaments or by specialised tentacles known as sweeper tentacles (e.g. Chornesky, 1983; a useful summary is given in Carlson, 1999, p. 97). These structures are also known in gorgonian polyps (Sebens \& Miles, 1988), so their presence in two subclasses of Anthozoa presents the interesting possibility that they may also have occurred in rugosans as well. There has been speculation as to whether or not rugosans had mesenteries (e.g. Birenheide, 1965), but it is more generally accepted that they were in fact present (see discussion in Hill, 1981). Thus the second possibility, aggression by means of mesenteric filaments, cannot be excluded.

\subsection{Settlement}

As shown above, there is an association between mortality crises in the growth of the host corallum and settlement by Symplectophyllum larvae. In other words, infection occurs at a time when the host is stressed, not unlike many other infections.

Not all colonies of Syringopora are infected, and the level of infection varies considerably. As the infections are apparently associated with the crises in corallum growth of the host, and these crises are also apparent in uninfected colonies, I suggest that there is a further parameter, not apparent in the fossil record, related to the timing of spawning. Only when a mortality crisis is followed by a spawning event before the corallum has had a chance to recover is the infection great.

\subsection{Size of "mature" corallites}

Continued growth of corallites at diameters less than those achieved by the largest individuals, a constraint only apparent in those specimens situated in actively growing Syringopora colonies, offers a clue that the Symplectophyllum may not remain completely unaffected by its host. Nonetheless, quite large individuals of Symplectophyllum do indeed occur within Syringopora colonies (Fig. 8), so this relationship needs to be explored further.

\subsection{Other bioassociations}

Intimate associations of unrelated cnidarian species are not unknown from the Palaeozoic. That of Syringopora or Syringoporella immersed in massive stromatoporoids, the association famously described as Caunopora by Phillips (1841), is probably the best-known. Hill (1942a, b) has described Spongophyllum immersum and Eridophyllum immersum from the Devonian of eastern Australia, both fasciculate species, and, as suggested by their name, immersed in massive stromatoporoids. Associations of two coral species are rarer, but, from Ohio, Sorauf \& Kissling (2012) have described rugosans "immured" in the tabulate coral Paleofavosites.

In the first case, it is possible that the additional support afforded by the massive stromatoporoid for the fine, branching coralla of Syringopora and Syringoporella enabled these forms to colonise more energetic environments than otherwise would have been possible. Hill's figures, particularly those of E. immersum, show a contour-like disposition of the stromatoporoid laminae around the corallites, implying that the corallites occupied high points (not mamelons) on the stromatoporoid, or, more likely, that the sponge occupied lower levels of the corallum and encrusted protuberant corallites. Thus the stromatoporoid probably used the branching corallum for the most part merely as a substrate. Further examination of all of these sponge-coral associations, particularly the physical relationships at the growing surfaces, is necessary to clarify their dynamics.

More significant in the present context is the coral-coral association described by Sorauf \& Kissling (2012). Several specimens of an undescribed species of the solitary rugosan genus Streptelasma show unequivocal evidence of having settled on the surface of the tabulate Paleofavosites, subsequently overgrowing several corallites of the host. That part of the epitheca of Streptelasma lying against its host is variously modified, whereas the exposed part is normally developed. The authors concluded (p. 224) that this species "occupied a higher position in the coral aggression hierarchy, presumably by possessing more power toxins and a superior means of delivering such toxins, perhaps analogous to these aggressive mechanisms (cnidoblasts, extrusion of digestive filaments) found among modern scleractinian corals". This aggressive tactic by the Streptelasma is analogous to that of Symplectophyllum, but probably did not employ the same means, since there is no indication of an areola associated with the invading individual, although it managed to maintain its access to ocean water by preventing overgrowth by the Paleofavosites. Favositid corallites were undoubtedly killed during growth of the Streptelasma, which itself was only overgrown by the Paleofavosites after death. Not touched upon by these authors is how the larval settlement actually occurred. Unlike the fasciculate Syringopora, in the cerioid Paleofavosites there was no exposed epitheca (or alga-encrusted epitheca) available for larval settlement.

\section{Conclusions}

Symplectophyllum larvae settled on the alga-encrusted epitheca of Syringopora corallites, or, less commonly, fasciculate lithostrotionids. Growing Symplectophyllum is able to overwhelm adjacent Syringopora corallites, thus achieving on the one hand firm attachment and on the other, space to grow. It is speculated that this may be initiated by interference between the tentacles of the two species concerned, by some chemical method, or most likely through the action of sweeper tentacles similar to those known from modern anthozoans. There is some evidence that settlement of, or at least, successful colonisation by Symplectophyllum larvae may have been advantaged by environmental events causing localised mortality of corallites within the host colony.

The earliest growth stages of Symplectophyllum are characterised by attachment and associated modification of the epitheca on the cardinal side, early insertion of the cardinal and counter septa, and a subsequent rather irregular appearance of the major septa. The early and continued development of lonsdaleoid dissepiments conferred on the marginarium a developmental plasticity admirably suited to accommodating the shape of the corallite to its support throughout its life, with minimal energy expenditure. 


\section{Acknowledgements}

I am grateful to Peter Cupitt of "Pinaroo Plain", Bingara, for the loan of the specimen illustrated in Fig. 5; this specimen, more than any other, is the one which triggered consideration of interactions between the species involved. Colleagues Ian Percival and Mikołaj Zapalski read the manuscript at an early stage, and I am pleased to acknowledge their advice. I am also grateful to reviewers Błazej Berkowski and Sergio Rodriguez for insightful comments. The photographs are the work of David Barnes, and he and Yongyi Zhen worked on the composite figures. The article is published with the permission of the Executive Director, Geological Survey of New South Wales, the institution which provided the research facilities.

\section{References}

Benson, W.N., \& Smith, S. 1923. On some rugose corals from the Burindi Series of New South Wales. Quarterly Journal of the Geological Society of London 74/2, 156-171.

Berkowski, B., 2012. Life strategies and function of dissepiments in rugose coral Catactoteochus instabilis from the Lower Devonian of Morocco. Acta Palaeontological Polonica 57/2, 391-400.

Birenheide, R., 1965. Haben die rugosen Korallen Mesenterien gehabt? Senckenbergiana lethaea 46/1, 27-34.

Carlson, R.H., 1999. Dynamics of coral communities. Kluwer Academic Publishers, Population and Community Biology Series 23, $257 \mathrm{p}$

Chesnut, W.S., Flood, R.H., McKelvey, B.C., \& Cameron, R.G., 1969. Manilla. 1:250,000 geological series Sheet SH 56-9. Geological Survey of New South Wales, Sydney.

Chornesky, E., 1983. Induced development of sweeper tentacles on the reef coral Agaricia agaricites: a response to direct competition. Biological Bulletin 165, 569-581.

Denayer, J., \& Webb, G., 2015. Cionodendron and related lithostrotionid genera from the Mississippian of eastern Australia: systematics, stratigraphy and evolution. Alcheringa 39, 315-376.

Dun, W.S., \& Benson, W.N., 1920. Section B. Palaeontology. In: Benson, W.N., Dun, W.S., \& Browne, W.R. (eds), The geology, palaeontology and petrography of the Currabubula District, with notes on adjacent regions. Proceedings of the Linnean Society of New South Wales 45, 337-374.

Hill, D., 1934. The Lower Carboniferous corals of Australia. Proceedings of the Royal Society of Queensland 45/12, 63-115

Hill, D., 1942a. The Middle Devonian rugose corals of Queensland, III. Burdekin Downs, Fanning R., and Reid Gap, North Queensland. Proceedings of the Royal Society of Queensland 53, 229-268.

Hill, D., 1942b. Middle Palaeozoic rugose corals from the Wellington district, N.S.W. Journal and Proceedings of the Royal Society of New South Wales 76, 182-189.

Hill, D., 1981. Treatise on Invertebrate Paleontology F. Supplement 1, Rugosa, Tabulata, vol. 1, 378 p. Geological Society of America (Boulder, Colorado) and University of Kansas (Lawrence, Kansas).

Jenkins, T.B.H., Crane, D.T., \& Mory, A.J., 1993. Conodont biostratigraphy of the Viséan Series in eastern Australia. Alcheringa 17, 211-283.

McKelvey, B.C., \& White, A.H., 1964. Geological map or New England 1:100,000, Horton Sheet (No. 290), with marginal text. University of New England, Armidale, New South Wales, Australia.

Percival, I.G., 2010. Appendix 2 - Palaeontology Report. In Vickery, N.M., Brown, R.E. \& Percival, I.G., Explanatory notes, Manilla 1:100,000 Geological Sheet 9036. Geological Survey of New South Wales.

Phillips, J., 1841. Figures and descriptions of the Palaeozoic fossils of Cornwall, Devon and West Somerset. 231 p. Geological Survey of Great Britain and Northern Ireland.

Pickett, J.W., 1967. Lower Carboniferous coral faunas from the New England District of New South Wales. Memoirs of the Geological Survey of New South Wales, Palaeontology 15, 1-38.

Roberts, J., Jones, P.J., \& Jenkins, T.B.H., 1993. Revised correlations for Carboniferous marine invertebrate zones of eastern Australia. Alcheringa 17, 353-376.

Roberts, J., \& Oversby, B.S., 1974. The Lower Carboniferous geology of the Rouchel District, New South Wales. Bureau of Mineral Resources, Geology and Geophysics, Bulletin 147, 1-93.

Sebens, K.P., \& Miles, J.S., 1988. Sweeper tentacles in a gorgonian octocoral: morphological modifications for interference competition. Biological Bulletin 175, 378-387.

Sorauf, J.E., 2007. The function of dissepiments and marginaria in the Rugosa (Cnidaria, Zoantharia). In Hubmann, B., \& Piller, W.E. (eds), Fossil Corals and Sponges, Proceedings of the 9th International Symposium of Fossil Cnidaria and Porifera, Graz, 2003. Austrian Academy of Sciences, Schriftenreihe der Erdwissenschaftlichen Kommissionen 17, 11-29.
Sorauf, J.E., \& Kissling, D.L., 2012. Rugosans immured in Silurian Paleofavosites; Brassfield Formation (Llandovery) of Ohio. In Denayer, J., Aretz, M., \& Poty, E. (eds), Proceedings of the 11th International Symposium on Fossil Cnidaria and Porifera, Liège, 2011. Geologica Belgica 15, 220-225.

Manuscript received 17.08.2015, accepted in revised form 27.09.2015, available on line 04.02.2016.

\section{Appendix: Early ontogeny of Symplectophyllum}

In the following descriptions, in order to distinguish between corallites, species and specimens in concise fashion the following convention has been followed: the three Symplectophyllum individuals whose ontogeny is followed are referred to as SymA, SymB and SymC. Syringopora corallites associated with them are similarly designated SyrA, SyrB, SyrC, with the addition of a number (e.g. SyrB3) to identify individual corallites within a corallum. Additionally, the use of the terms "left" and "right" referring to quadrants within Symplectophyllum corallites, is based on the convention of illustrating rugosans with the cardinal septum at the lowest point of a transverse section.

All three specimens lie within a single corallum of Syringopora, MMF25300, from the Glenbawn locality. Prior to preparation the (eroded) corallum had diameters of $15 \mathrm{~cm} \mathrm{x}$ $12 \mathrm{~cm}$ and was $9 \mathrm{~cm}$ high. On its upper surface 17 individuals of Symplectophyllum were exposed. Sixty-four peels were made at nominal intervals of $0.3 \mathrm{~mm}$, using a Croft parallel grinder, and lightly etching the resulting surface with dilute $\mathrm{HCl}$. The interval between peels is however imperfect, as the specimen became dislodged from the mount a number of times and had to be re-set. Nonetheless, the order of peels is correct, even if the intervals between them are not perfectly regular.

\section{Symplectophyllum corallite A (Figs 11, 12)}

Peel 1: The peel is imperfect, but the juvenile SymA has a reniform outline, flattened on the side by which it is attached. The attachment is not directly to a Syringopora corallite, but to an algal incrustation on it. The alga continued to grow after settlement of the planula, as the young coral is completely embedded in algal tissue. A single septum, or possibly the cardinal counter pair, traverses the entire lumen. The cardinal septum is apparently on the attached side. The dimensions are $1.6 \times 1.0 \mathrm{~mm}$.

Peel 2: SymA has diameters of $1.5 \times 1.0 \mathrm{~mm}$, and six septa. The cardinal-counter pair is continuous across the lumen. The alar pair is next strongest, while the counter-laterals are mere stubs. The outline remains reniform, and the coral is completely enveloped by algal tissue.

Peel 3: Diameters $1.5 \times 1.2 \mathrm{~mm}$, eight septa. The corallite is attached, not to a Syringopora corallite (SyrA1), but to a calcareous algal encrustation on it. The calyx of the Syringopora is filled with mud and the section is above the syrinx, so presumably the polyp was dead.

Peel 7: Dimensions $1.5 \times 1.2 \mathrm{~mm}$, ca 9 septa. The short diameter is the $\mathrm{C}-\mathrm{K}$ axis. The tip of the cardinal septum is swollen, suggesting incipient axial structure.

Peel 10: Dimensions $3.5 \times 2.4 \mathrm{~mm}$. The left cardinal quadrant has begun to expand, so the greater diameter is in this direction. There is an axial structure of a single lamella normal to the C-K plane.

Peel 12: Dimensions $3.5 \times 3.0$ (reconstructed) $\mathrm{mm}$. The first dissepiment (lonsdaleoid) has appeared to the right of the counter septum. Part of the right side, mostly in the cardinal quadrant, has been lost by pressure solution.

Peel 15: The corallite has a well-developed talon, reaching across to the adjacent Syringopora corallite, the attachment curved to conform to the shape of the encrusted corallite. However, the attachment is not to the corallite epitheca, but to a $0.4 \mathrm{~mm}$ thick incrustation on it. Corallite dimensions (without talon) are $3.9 \mathrm{x}$ $3.0 \mathrm{~mm}$, with the talon the maximum diameter is $6.0 \mathrm{~mm}$. There are 19 septa, all of them major, and two lonsdaleoid dissepiments on the counter side. The axial complex involves the cardinal and counter septa and a few indistinct lamellae. The talon occupies the entire left cardinal quadrant. 

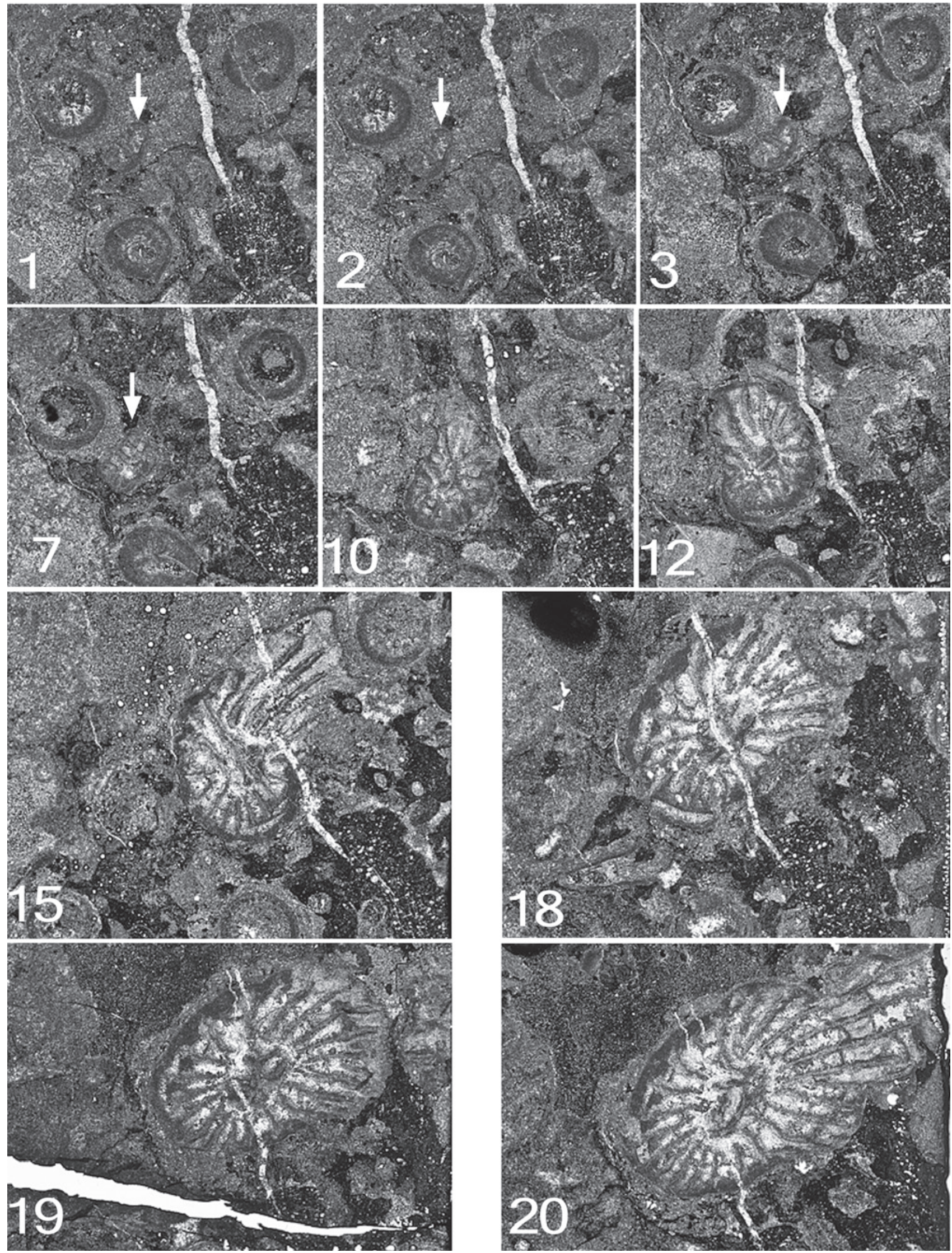

Figure 11. Symplectophyllum corallites examined by serial section. Sections prepared from block remaining after serial sectioning, with sectioned corallites identified. Section in A is older than that in B. Note aureolae, particularly around SymB. MMF25300, Dangarfield Formation, Glenbawn Dam. Both x 3.

Peel 18: The talon remains well-developed, partly encircling the encrustation on the Syringopora corallite. There are still 19 septa and the edge of the talon includes the first of the minor septa. There is a single lonsdaleoid dissepiment in the right counter quadrant. Dimensions $5.1 \times 3.6 \mathrm{~mm}$.

Peel 19: The Symplectophyllum corallite is no longer attached. The outline is more oval, though still distorted. There are now three minor septa. The axial structure has become separate from the septa proper, with ca seven lamellae in varying orientation. Dimensions $6.2 \times 3.9 \mathrm{~mm}$ without talon; with talon the maximum is $>9.00 \mathrm{~mm}$, the epitheca now lying beyond the edge of the block. The corallite is at the point where it has just overgrown the Syringopora corallite, which no longer appears in the section; part of the talon appears separated from the main corallite, where 


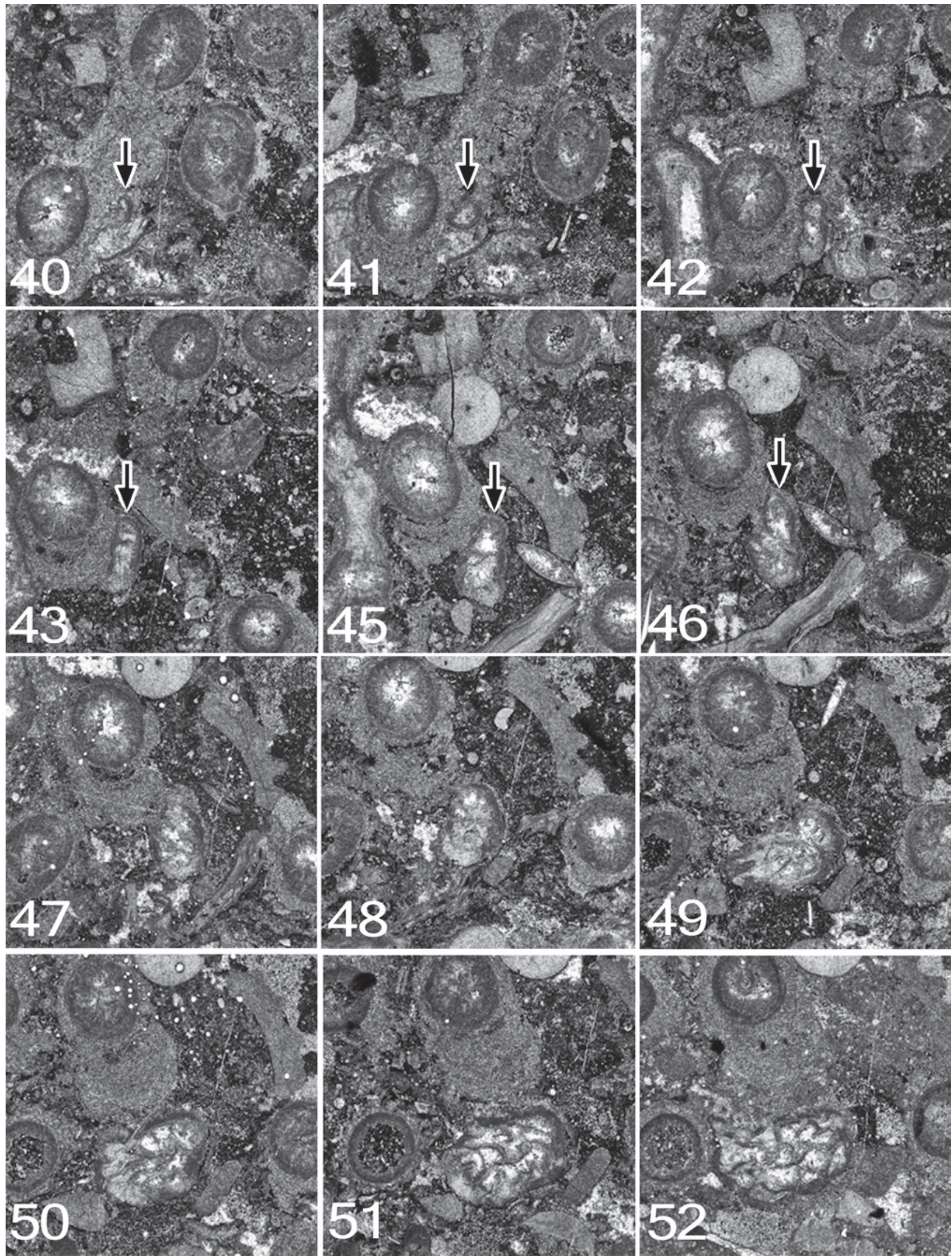

Figure 12. Symplectophyllum corallite A. Note that component figures are not numbered serially, but according to the peel from which they were taken. MMF25300, Dangarfield Formation, Glenbawn Dam. All x 7.3.

it has apparently extended below the Syringopora calyx.

Peel 20: The talon reaches right to the sawn edge of the block. Minor septa have disappeared. There are 23 major septa. Dimensions $>8.5$ x $4.0 \mathrm{~mm}$.

Further growth: At the end of serial sectioning (peel 64) the corallite is still healthy, and continues beyond the stub, from which two thin sections were made. The corallite at this level is illustrated in Fig. 11. At the level of peel 64 it has 28 major septa and a well-developed marginarium. The columella is the typical tangled Symplectophyllum structure and is $2.5 \times 1.4 \mathrm{~mm}$ in size. The position of the corallite at the corner of the block means that it is incomplete, but would have had diameters of approximately $13 \times 10 \mathrm{~mm}$. 


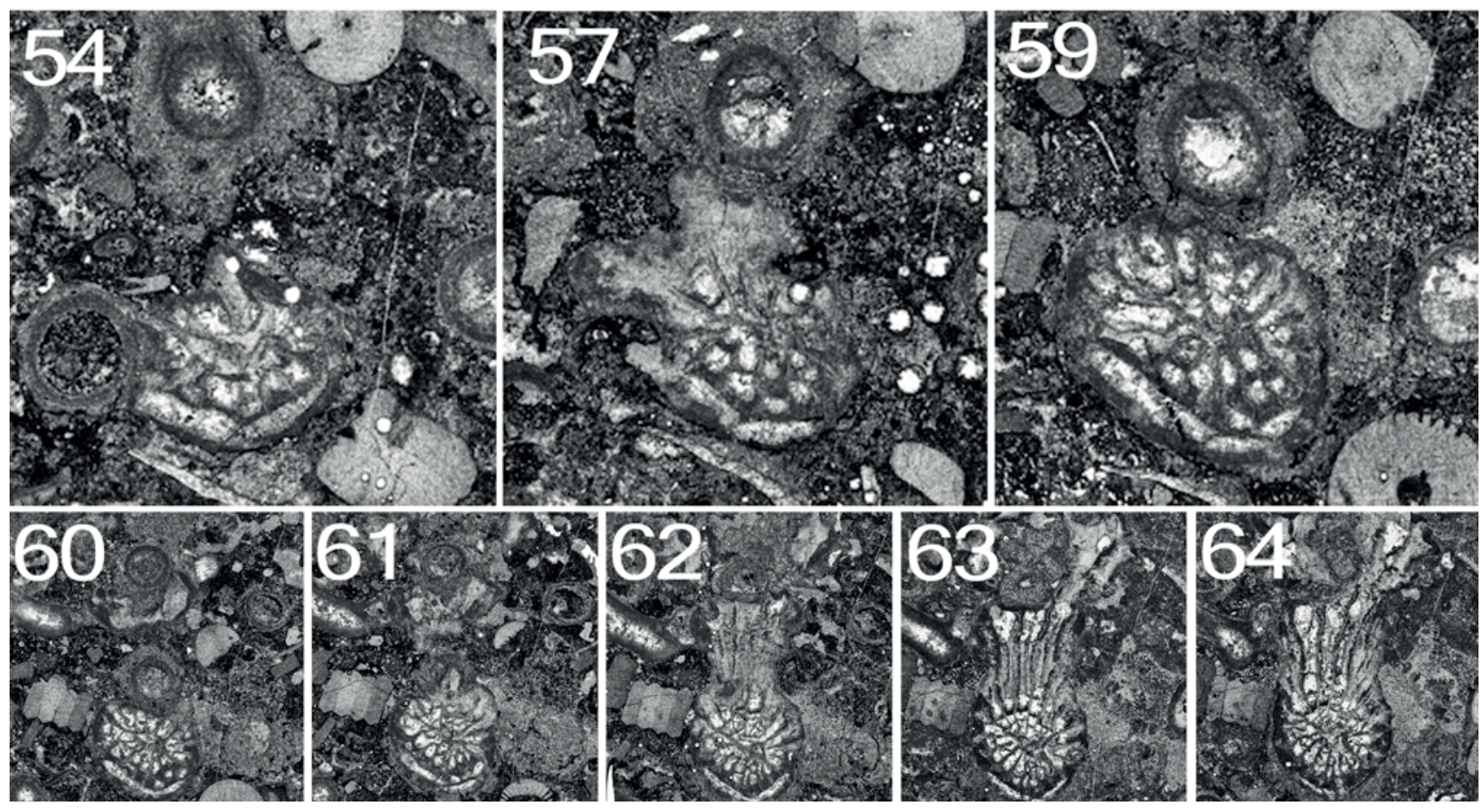

Figure 13. Symplectophyllum corallite B. Note that component figures are not numbered serially, but according to the peel from which they were taken. MMF25300, Dangarfield Formation, Glenbawn Dam. All x 7.3.

\section{Symplectophyllum corallite B (Figs 11, 13, 14)}

Peel 40: This corallite (SymB) can be traced from a slightly earlier stage than corallite SymA. The larva has apparently settled on the encrustation on the side of a Syringopora corallite (SyrB1). The calcite-filled lumen of the SyrB1 indicates that this was at a level below the calyx, but it can't be determined if the polyp was alive at the time. The juvenile SymB consists of the epitheca and a single septum, presumably the cardinal. The corallite is slightly reniform in outline, flattened on the side by which it is attached (the cardinal side). It measures $0.6 \times 0.3 \mathrm{~mm}$.

Peel 41: SymB is flattened on one side and measures $1.0 \mathrm{x}$ $0.7 \mathrm{~mm}$. No septa are visible.

Peel 42: SymB rather elongated laterally, somewhat irregular. One septum is visible. Dimensions $1.8 \times 0.8 \mathrm{~mm}$.

Peel 43: SymB remains flattened on the attached side but has increased in size to $2.0 \times 0.8 \mathrm{~mm}$. There is still only one septum.

Peel 45: There are now three septa, and possibly the stubs of two others. The outline is irregularly ovoid. SymB is attached to SyrB 1 by only a small part of its circumference. Dimensions 2.2 x $1.2 \mathrm{~mm}$.

Peel 46: The attachment to SyrB1 is now only slight, at the narrower end of the ovoid outline. There are seven septa, and for the first time the section appears recognisably that of a coral. Dimensions $2.4 \times 1.3 \mathrm{~mm}$.

Peel 48: SymB all but free of substrate, almost surrounded by muddy sediment. There are now 10 septa.

Peel 49: SymB has begun to extend laterally at $90^{\circ}$ to its original attachment. There are 10 , possibly 11 septa.

Peel 50: The lateral extension is still present. There are 12 septa and an incipient axial structure.

Peel 51: SymB is now free of substrate, probably with its own algal incrustation. There are 10 septa, the 4 longer ones slightly contorted at the axis. The first lonsdaleoid dissepiments have appeared.

Peel 52: SymB has developed a talon connecting it to a Syringopora corallite (SyrB2), different from the one to which it was originally attached. The distal end of the talon is concave, conforming to the shape of the encrustation on SyrB2. There are 10 possibly 11 septa.

Peel 54: The talon is well-developed, firmly attached to a dead corallite (SyrB2), whose calyx is filled with mud and shows no tabulae, so was dead. There are 13 septa and 2 large lonsdaleoid dissepiments.

Peel 57: SymB is still attached to SyrB2, but the latter is represented only by a discontinuous calical wall. A new talon has begun to extend across to the Syringopora corallite (SyrB1) which afforded the original attachment.

Peel 59: SyrB2 has now disappeared, and the attachment to the incrustation of corallite SyrB1 is loosely retained. There are now 3 lonsdaleoid dissepiments, one quite large, cutting off 3 septa of the now 18.

Peels 59 - 64 illustrate an interesting event. Diametrically opposite corallite SyrB1 from the point of attachment lies a third Syringopora corallite, SyrB3, which in peel 59 is filled with sediment and was apparently dead. SymB at this level is effectively free of any attachment. The lumen of SyrB1 is calcite-filled, so it may still have been alive. Peel 60 shows Symplectophyllum skeletal tissue, isolated from that of SymB, surrounding the incrustation on SyrB3 for almost half its diameter. SymB is now expanding around SyrB1 for ca 1/3 of its diameter. Peel 61 shows a greater area of Symplectophyllum tissue attached to SyrB3, and the skeleton of SymB has all but engulfed SyrB1. In peel $62 \mathrm{SyrB} 1$ has disappeared altogether, and the coral tissue against SyrB3 in earlier sections is revealed to be part of SymB as the two have fused, and the septa run continuously from the main corallite through its extension. In peel $63 \mathrm{SyrB} 3$ has also disappeared, and the talon now overgrows algal material of the incrustation. In the final peel the talon has extended well beyond the position of SyrB3. In the youngest observed stages (in thin section) the coral is sub-rounded and has achieved diameters of $9.5 \times 8.0 \mathrm{~mm}$, has 24 septa of each order, a well-developed axial structure $2.0 \times 2.5$ $\mathrm{mm}$ in diameter and a fully developed marginarium.

This means that during growth the young Symplectophyllum corallite has successively engulfed corallites SyrB2, SyrB1 and SyrB3, in that order, although the original attachment was to SyrB1.

\section{Symplectophyllum corallite C (Figs 11, 15)}

Less than $1 \mathrm{~cm}$ from SymB there is another juvenile corallite, SymC, possibly from the same settlement event. If so, the planulae settled at slightly different levels $(2.7 \mathrm{~mm}$ apart $)$ within the Syringopora colony, as the development of SymB is in advance of that of SymC. 

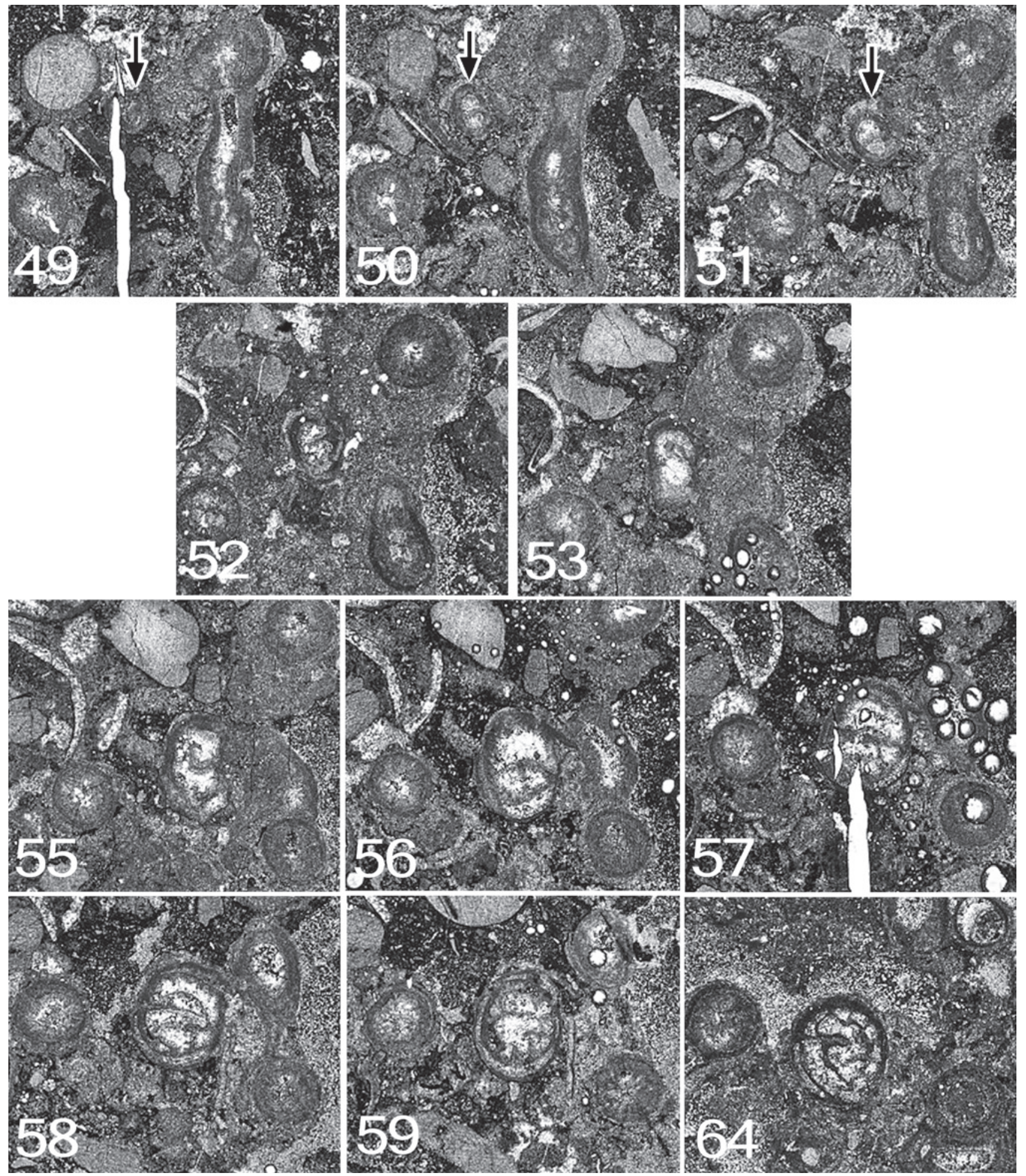

Figure 14. Symplectophyllum corallite B, continued from Fig. 13. Note that component figures are not numbered serially, but according to the peel from which they were taken. MMF25300, Dangarfield Formation, Glenbawn Dam. Upper row x 7.3, lower row x 4.1.

Peel 49: SymC is present as a simple ring of epitheca, apparently attached to the algal incrustation on a Syringopora corallite $(\mathrm{SyrC1})$ at the same level as an offset. The thickness of the algal incrustation $(1.1 \mathrm{~mm})$ is almost as great as the diameter of SyrC1. SymC measures 1.4 x $1.0 \mathrm{~mm}$. The lumen of the offset is connected to that of SyrC1.

Peel 50: SymC has not increased in diameter, but is somewhat reniform, the flattened side being that of the attachment. There is a single septum, presumably the cardinal, arising from the epitheca on the concave side. The offset $(\mathrm{SyrC} 2)$ is still attached to its parent, and retains a narrow elongation in that direction, though the lumina are no longer connected. The distance between the axes of $\mathrm{SyrC} 1$ and $\mathrm{SyrC} 2$ is $5.0 \mathrm{~mm}$.
Peel 51: SymC still has only 1 septum and measures $1.4 \mathrm{x}$ $1.1 \mathrm{~mm}$. SyrC2 has now separated from its parent, but is elongated in that direction.

Peel 52: SymC has increased in size to $1.8 \times 1.2 \mathrm{~mm}$. The cardinal septum is long, traversing $3 / 4$ of the lumen. There are 2 septal stubs in the left double quadrant, at ca $45^{\circ}$ and $90^{\circ}$ to the cardinal septum.

Peel 53: SymC is attached by nearly half of its diameter and is indented at the position of the cardinal septum, which is long. Only one septal stub can be identified, almost within the epitheca, in the left cardinal quadrant.

Peel 55: SymC remains reniform in outline, and measures 2.5 $\mathrm{x} 1.6 \mathrm{~mm}$. The cardinal septum is turned abruptly to the right at 

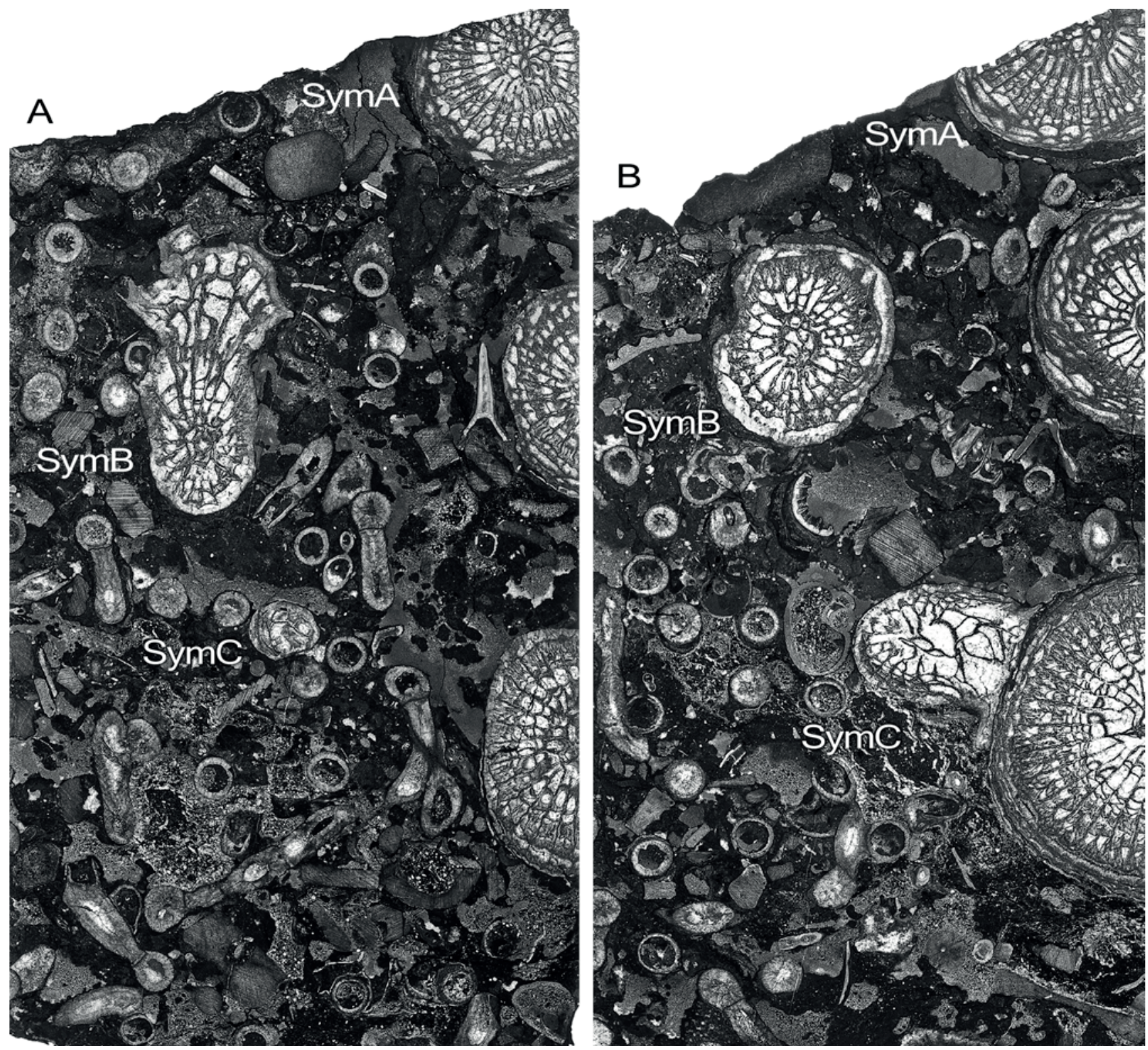

Figure 15. Symplectophyllum corallite C. Note that component figures are not numbered serially, but according to the peel from which they were taken. MMF25300, Dangarfield Formation, Glenbawn Dam. All x 7.3. (12 sub-figs; 11 peels, 1 section).

about half length. A smaller second septum appears to rise next to the cardinal of the left side. The outermost line of the epitheca is discontinuous and there is a small patch of sediment infill, suggesting rejuvenescence even in such an early stage. SyrC2 has now put out an offset $(\mathrm{SyrC} 3)$ in the direction of its own parent, SyrC1. Its lumen is not connected with that of SyrC2.

Peel 56: SymC now has a rather pointed lobe or small talon lying between the algal incrustation and the margin of SyrC3, which is attached by its epitheca to $\mathrm{SyrC} 2$ and is elongate in outline. SymC shows no recognisable septa, but has instead five thin plates in uninterpretable position, apparently early tabulae. The two smallest of these occupy the lobe. Dimensions of SymC $2.6 \times 1.5 \mathrm{~mm}$.

Peel 57: $\mathrm{SyrC} 3$ has now separated from its parent. The small talon of SymC has extended to occupy much of the space between $\mathrm{SyrC} 2$ and $\mathrm{SyrC} 3$, but this tissue lies outside the general outline of the corallite proper, which now measures $2.8 \times 2.1 \mathrm{~mm}$. There is a lonsdaleoid dissepiment along the left cardinal quadrant. A recognisable counter septum has appeared, opposite to and slightly shorter than the cardinal. The cardinal septum is slightly swollen at the axial end. The distance between the axes of SyrC1 and $\mathrm{SyrC} 2$ is now $5.4 \mathrm{~mm}$

Peel 58: $\mathrm{SyrC} 3$ is connected to $\mathrm{SyrC} 2$ by only a narrow strip of epithecal tissue, and presents the appearance of a submature corallite. SymC has extended the talon well into the embayment between $\mathrm{SyrC} 2$ and $\mathrm{SyrC} 3$, but otherwise remains subrounded in outline. Both cardinal and counter septa are long, and on the right are two septal stubs, one in the alar position and the other in the right cardinal quadrant. Excluding the talon, SymC measures 2.8 x $2.5 \mathrm{~mm}$. There are at least 2 lonsdaleoid dissepiments and a couple of tabulae.

Peel 59: The talon of SymC has disappeared, and the corallite is all but free of any algal incrustation. There are 11 septa and a complete dissepimentarium of a single row of lonsdaleoid dissepiments. Diameters 2.8 x $2.1 \mathrm{~mm}$.

Peel 64: There are still 11 septa. The dissepimentarium is again incomplete, with only a single lonsdaleoid dissepiment in the left counter quadrant. Diameters $2.5 \times 2.2 \mathrm{~mm}$.

In the youngest thin section (Fig. 11B), when it would have been $14.7 \mathrm{~mm}$ high, SymC is still healthy, but has developed a talon which attaches it to a much older Symplectophyllum individual. Here its dimensions are 7.8 x $5.8 \mathrm{~mm}$; it has 18 major septa but only a few rudimentary minor septa, and the axial complex is merely a single lamella in the counter-cardinal plane.

From the above it emerges that juvenile Symplectophyllum corallites can continue to survive within the actively growing part of a Syringopora colony. Over a vertical interval of $3 \mathrm{~mm}$ the Syringopora has produced two new corallites immediately adjacent to the juvenile Symplectophyllum, which has increased in size from $1.4 \times 1.0 \mathrm{~mm}$ to $2.8 \times 2.1 \mathrm{~mm}$. While the Syringopora corallites rapidly reach adult size, and even produce offsets of their own, the Symplectophyllum remains very much a juvenile. 